\title{
Income Inequality, Ecological Footprint, and Carbon Dioxide Emissions in Asian Developing Economies: What Effects What and How?
}

\section{Salim Khan}

Zhengzhou University

Wang Yahong ( $\sim$ wyahong2009@zzu.edu.cn )

Zhengzhou University https://orcid.org/0000-0001-7224-6630

\section{Research Article}

Keywords: Income inequality, Ecological footprint, Carbon emissions, Environmental degradation, Developing economies

Posted Date: August 3rd, 2021

DOI: https://doi.org/10.21203/rs.3.rs-687484/v1

License: (c) (i) This work is licensed under a Creative Commons Attribution 4.0 International License. Read Full License

Version of Record: A version of this preprint was published at Environmental Science and Pollution Research on November 26th, 2021. See the published version at https://doi.org/10.1007/s11356-02117582-4. 


\section{Abstract}

The reduction of income inequality and environmental vulnerability are two most important factors, through which we can achieve the target of Sustainable Development Goals (SDGs). The past papers have investigated the nexus between income inequality and carbon emissions, however, the relationship between income inequality and carbon emissions along with ecological footprint needs to be considered. To this end, the objective of current study is to reveals the causal association between income inequality and environmental vulnerability (the ecological footprint and carbon emissions used as a measures of environmental vulnerability) by using the dataset from 2006 to 2017 for the 18 Asian developing economies. The empirical results obtained from Driscoll and Kraay (D\&K) standard error estimator confirmed the casual linkages between income inequality, ecological footprint, and carbon emissions. Furthermore, foreign direct investment, easy access to electricity, and population growth control income inequality, but they have a detrimental effect on both ecological footprint and carbon emissions. Lastly, based on our empirical findings, some important policy implications are recommended.

\section{Introduction}

Is that possible for developing economies to meet environmental goals and also ensure low income inequality? Does economic growth can break vicious circle of poverty, mainly, if it is not link with increasing environmental degradation and income inequality? These questions are theoretically and empirically ambiguous as rising environmental degradation income inequality, and poverty are major challenges facing every human being in the 21 st century. Despite a significant alleviation in the poverty level from the last few years, many developing countries still facing the problem of increasing income inequality (Baloch et al., 2020a). In contrast, the level of toxic emissions (Carbon emissions, ecological footprint etc.) are reaching to its limits and crossing dangerous zone (Steffen et al. 2015). There are large numbers of research studies that investigates the association between inequality and toxic emissions, the green-house or conservatory effect is mainly responsible for the rising global warming and climate change. Many research studies in the literature proposes that economic growth, however, up to certain level of economic development, upsurges global warming and green-house gases emissions (Forabosco et al., 2017; Edenhofer et al., 2014; Tyler et al., 2017). Subsequently, in the context of least developed countries, higher economic growth may ensure reduction in poverty, but increase environmental degradation. An interrelated problem is whether the trade-off situation exists between income inequality and environmental degradation, as suggested by the work of Ravallion et al. (2000). As the readers will see below, the empirical and theoretical studies produces miscellaneous findings on this issue, pointing to different mechanisms and effect (for a survey see Berthe and Elie, 2015). Mostly past research papers are, however, based on rather simple analytical techniques and old data, therefore, in current study, we improve the existing literature in both of these prospects, that is, apply advance econometric techniques and incorporated expanded data.

In the meantime, increasing income gap between rich and poor creates a miscellaneous consequences on different social classes of the society (Liu et al., 2020). The poor people of the society get more affected 
from the income inequality since they are an extremely vulnerable part of the society. In addition, rising income inequality degrading environment by generating problem in the way of policy implications. Likewise, income inequality might leads to less environmental protection and eventually responsible for environmental degradation. Furthermore, it is argued that higher income gap increases environmental degradation through voting and ownership channels (Hailemariam et al., 2020). Meanwhile, it is further documented that better environmental quality could be significant for the reduction of absolute poverty (Dorn et al., 2021; Xi, 2020). Natural (environmental) resources help to reduce alleviate poverty and inequality by providing equal and better health facilities, equal access to food and job opportunities (Lawson et al., 2012). Alternatively, environmental pollution can be controlled by controlling increasing income gap, mainly in less developed countries. It is argued that environmental degradation and rising income inequality are strongly associated with one and the other. Low income group is vastly dependable on the environmental resources and therefore they manipulates resources in an unsustainable way that increases environmental degradation (Finco, 2009).

In this situation, the two most important approaches have been emerged as a top priorities for researchers. On the one side, the researchers prioritize on the win to win solution, such as, the concern authorities and policy makers of a country should perform sound by reducing poverty and income inequality with worthy socioeconomic and healthier quality of environment. Regarding this mechanical tactic, if some elements controlling degrading environment also supportive for alleviation of poverty and reducing income inequality, counties' economic performance will be better and they could enjoy sound environmental quality. On the other side, the trade-off situation (approach), policy makers and concern authorities either maintain clean and better environmental quality or embrace income inequality and poverty (Zhao et al., 2021; Wang, 2014). In other words, some factors that help to control ecological vulnerability also contributes to rise the ratio of low income people, while it further generates a trade-off situation between environment and economic targets. The main inspiration of the above deep-rooted discussion in the association between environment, poverty, and income inequality. Definitely, achieving higher economic growth is significant for reduction of poverty, if it is not linked with increasing inequality. Although, for stable and long-run economic growth, energy consumption is a main and key component (Luqman et al., 2019). From the last few years, numerous economic activities have been originated to satisfy human need and increase their standard of living. Nevertheless, the above-mentioned economic determinations have raised the aggregate demand for gas, oil and coal energy sources (fossil energy) that degrading the quality of environment (Aydin, 2019; Wang et al., 2018). In this manner, economic prosperity link with fossil energy sources and raise the living standard of low income people. Whereas, alternatively, it also cause ecological vulnerability (Wang and Feng, 2017).

It can be also observed that low-income countries suffer more from trade-off situation in response to environmental mitigation effort than high-income countries. This is because, low-income people from developing countries mainly dependable on environmental resources to fulfill their basic life needs, and therefore, degrading the quality of environment (Rai and Soni, 2019). Thus, it is not easy for policy makers to maintain the wellbeing of low-income people without compromising environmental quality. Because of this ambiguous trade-off situation, policy makers trying to reduce environmental degradation 
that might influence the low-income community at large (Meinard, 2021; Scolobig and Lilliestam 2016). By achieving these simultaneous objects might be a big challenge for policy makers, due to existing of trade-off situation between income inequality and environmental mitigation efforts.

Some studies investigated the relationship between income inequality and environmental degradation while they incorporated carbon emission (hereafter, $\mathrm{CO} 2 \mathrm{e}$ ) as a measure of ecological vulnerability. Contrasting from those previous studies, in present research study, we empirically analyze the nexuses between income inequality and environmental vulnerability by using both Co2e and ecological footprint (hereafter, EFP) as a proxies for environmental pollution for the cross countries panel of 18 Asian developing countries. The selection of utilizing both $\mathrm{CO} 2 \mathrm{e}$ and EFP for environmental pollution due to reason that the net effect of income inequality might not be limited to $\mathrm{CO} 2 \mathrm{e}$, which is most common and usable proxy for environmental degradation (Baloch et al., 2019b; Khan and Yahong, 2021). Nevertheless, income inequality may influence the air pollution at a high level including natural resources, for instance water, mining, forestry and soil (Zaidi and Saidi, 2018). Increasing the economic activities aiming to facilitate low-income people to reduce poverty, which deplete environment in the form of natural resources such (as forest, water, minerals, and land). Since, only taking CO2e as a measure of degradation might simply provide the narrow aspect of ecology and its vulnerability, and therefore, overlook the main humanoid activities that are responsible for ecological vulnerability. By investigating the impact of major humanoid activities on the ecology, EFP includes the land's actual capacity, and hence, it is a wide-ranging and perfect proxy for the vulnerability of ecology. The EFP has been used in few recent research studies such as, (Abbas et al., 2021; Baloch et al., 2020b; Charfeddine and Mrabet, 2017; Duro and Teixidó-Figueras, 2013; Kazemzadeh et al., 2021; Mikkelson; 2019; Mostafa, 2010; Solarin and Bello, 2019). According to Sustainable Development Goals (SDGs) sat by United Nation Development Programs (UNDP), EFP represents the natural competence of land for sustainable economic growth (Ekeocha, 2021).

In the current study we adds to existing literature in the some potential ways. Firstly, to the best to our knowledge, less or even no research so far empirically analyzed the trade-off situation between income inequality and environmental degradation by utilizing both CO2e and EFP. The empirical work of Grunewald et al. (2017) has studied the trade-off between income inequality and CO2e. Our study is motivated by Grunewald et al. (2017) research work to use both CO2e and EFP as a proxies for environmental pollution instead of only using CO2e. In this study, we have analyzed the net impact of income inequality on both CO2e and EFP as well as the actual impact of the CO2e and EFP on income inequality. Thus, our study would be a different and novel addition to the literature and would be a new contribution to the efforts for drawing attention to this empirically and theoretically ambiguous trade-off situation between income inequality and environmental degradation. Secondly, no cross-country panel study has investigated the relationship between income inequality and environmental degradation using both $\mathrm{CO} 2 \mathrm{e}$ and EFP by considering Asian developing countries. To the best of ours believe, the current research would fill the existing research gap and provide the useful insight for low-income countries in Asia. Thirdly, in this study we have applied advanced Driscoll and Kray (D\&K) econometric approach, which is reliable and provide robust results. 
The rest of the paper is structured as follows: Theoretical background and review of the literature is carried out in section-II. The methodology is covered in Section-III. Similarly, section-IV covers the empirical results of the study along with discussion. Section-V draws conclusion and suggest policy implications.

\section{Theoretical Background}

Many researchers have been documented that there might be inverted-U Shaped association between environmental degradation and inequality. In the literature, the empirical work of Grossman and Karueger (1995) suggested inverted-U shaped relationship between income and environmental degradation. This strong empirical evidence has confirmed the Environmental Kuznets-Curve (EKC). The EKC was the modification of the Kuznets-Curve (KC) introduced by Kuznets (1955). The concept of EKC-hypothesis and its possible causes such as income inequality, consumer preferences, technological progress, international trade, and governance presented by by Kaika and Zervas (2013a). While, in the revised version Kaika and Zervas (2013b) presented a comprehensive critical review on the EKC-hypothesis. The EKC-hypothesis between income and many other environmental toxins have been empirically studied with inconclusive findings. In recent past literature, EKC-hypothesis has mostly concentrated on $\mathrm{CO} 2 \mathrm{e}$, as it is considered to be the main driver of environmental degradation. The work of Hanewinkel et al (2013) and Tol (2002) argue the environmental costs related with environmental change for developed and least developed countries. There is no exactness on how the GDP growth can be decline, but there is some agreements on its indirect shocks. Determining whether the pattern of EKC-hypothesis holds for global environmental changes for instance $\mathrm{CO} 2 \mathrm{e}$ has main implications for policymakers because this arguments suggests a very resilient and balanced for the "grow-now, clean-later" idea that has been implemented by numerous developing economies.

The EKC-hypothesis pattern for environmental degradation has been mixed by many researchers such as Aslanidis and Iranzo (2009) investigate the non-homogeneous nature of relationship between income and $\mathrm{CO} 2 \mathrm{e}$ and filed to find the existence of EKC-hypothesis. On the other hand, Narayan and Narayan (2010) find this relationship in terms of both long and short-run income elasticities of environmental degradation revealed significant empirical evidence to support the EKC-hypothesis.

In recent literature, the empirical study on the EKC-hypothesis investigated by simply incorporating environmental degradation against income. However, this methodological approach suggests certain empirical and theoretical understandings about the process of economic development and environmental degradation, while its findings were inconclusive. The empirical model of EKC-hypothesis does not result in a good fit for many environmental pollutant. Since the literature of EKC-hypothesis established, it has become evident that taking income inequality into consideration is essential to understand the nexus between income and environmental degradation. (Grossman and Kaueger, 1995; Heerink et al., 2001).

The two most popular and important theories on how income inequality could have a positive influence on the quality of environment were introduce in rapid progression. The first theory of Ravallion et al. 
(2000) and Heerink et al. (2001) regarding income inequality and environmental degradation refer to as the theory of consumption. This theory provides a nonlinear association between environmental degradation and income inequality at household level. For instance, Cropper and Griffiths (1994) revealed that low level of household income, increase aggregate demand and/or consumption for firewood, that cause deforestation. Nevertheless, at higher level of household's income decreases the consumption level and/or demand for firewood as other advance forms of energy could be used. Depending on the threshold of income level, diverse behavior and manners might be observed. Additionally, income and CO2e reveals concave but positive association (Holtz-Eakin and Selden, 1995). According to Ravallion et al. (2000) and Heerink et al. (2001) if the relationship is purely concave at micro level, the theory predict an indirect and negative relationship between $\mathrm{CO} 2 \mathrm{e}$ and income inequality for a certain income level. The tested theory of Ravallion et al. (2000) and Heerink et al. (2001) find negative nexus and supported the existence of trade-off situation between reducing $\mathrm{CO}^{2} e$ and decreasing income inequality.

The second and most commonly discussed theory based on political economy regarding environmental degradation and income inequality introduced by Tarros and Boyce (1998). According to their proposed hypothesis that increasing income inequality will cause the aggregate demand of people for environmental quality. In environmental economics, the quality of environment considered to be an ordinary good, indicating that demand will be rise with increasing level of income. But those people who experience financially gain from high emitting activities might not demanding for good environmental quality as their level of income rises (Rojas-Vallejos and Lastuka, 2020). Another possible explanation of this theory that widening income-gap has leading role in pro economic growth reforms and for that, it is not essentially to consider environmental pollution. Irrespectively of the detail explanations, the mechanism of political economy suggests a direct relationship between environmental degradation and income inequality. Magnani (2000) check the validity of Torras and Boyce (1998) theory of political economy, while she also provides empirical evidence on decreasing income inequality help to reduce environmental degradation.

\section{Review Of The Literature}

In current study we investigates the nexus between income inequality and environmental degradation in terms of EFP and CO2e. For better understanding, we present the literature review in tabulated form, whereas the first column contains authors' name and years, second column represents country/region, the third column periods, fourth column presents method/methodology, while the last and fifth column presents the main results. 
Table 1

Summary of the literature review

$\begin{array}{llll}\text { Authors } & \text { Country/region } & \text { Period Methodology } & \text { Results }\end{array}$

Nexus between income inequality and environmental degradation.

\begin{tabular}{|c|c|c|c|c|}
\hline $\begin{array}{l}\text { Grunewal et al } \\
\text { (2017) }\end{array}$ & $\begin{array}{l}158 \text { developed and } \\
\text { developing economies }\end{array}$ & $\begin{array}{l}1980- \\
2008\end{array}$ & OLS, FE, GFE & Trade-off \\
\hline $\begin{array}{l}\text { Zhang and } \\
\text { Zhao, } 2014\end{array}$ & China & $\begin{array}{l}1995- \\
2010\end{array}$ & $\begin{array}{l}\text { Various panel regression } \\
\text { approaches }\end{array}$ & $\begin{array}{l}\text { Mixed } \\
\text { results }\end{array}$ \\
\hline $\begin{array}{l}\text { Jorgenson et } \\
\text { al., } 2017\end{array}$ & United States & $\begin{array}{l}1997- \\
2012\end{array}$ & P-W panel regression model & $\begin{array}{l}\text { Positive } \\
\text { relationship }\end{array}$ \\
\hline $\begin{array}{l}\text { Knight et al., } \\
2017\end{array}$ & Developed economies & $\begin{array}{l}2000- \\
2010\end{array}$ & Two way FE regression & $\begin{array}{l}\text { Positive } \\
\text { relationship }\end{array}$ \\
\hline Ota, 2017 & $\begin{array}{l}\text { Asian developing } \\
\text { economies }\end{array}$ & $\begin{array}{l}1990- \\
2000\end{array}$ & Trend-Analysis & $\begin{array}{l}\text { Mixed } \\
\text { results }\end{array}$ \\
\hline $\begin{array}{l}\text { Baloch et al., } \\
2018\end{array}$ & Pakistan & $\begin{array}{l}1966- \\
2011\end{array}$ & ARDL & $\begin{array}{l}\text { Positive } \\
\text { relationship }\end{array}$ \\
\hline $\begin{array}{l}\text { Masud et al., } \\
2018\end{array}$ & $\begin{array}{l}\text { Vietnam, Thailand, } \\
\text { Malaysia, Philippines } \\
\text { Indonesia }\end{array}$ & $\begin{array}{l}1985- \\
2015\end{array}$ & $\begin{array}{l}\text { Panel regressions and } \\
\text { Granger causality }\end{array}$ & $\begin{array}{l}\text { Mixed } \\
\text { results }\end{array}$ \\
\hline $\begin{array}{l}\text { Demir et al., } \\
2019\end{array}$ & Turkey & $\begin{array}{l}1963- \\
2011\end{array}$ & ARDL & $\begin{array}{l}\text { Negative } \\
\text { relationship }\end{array}$ \\
\hline $\begin{array}{l}\text { Bhattacharya, } \\
2019\end{array}$ & India & $\begin{array}{l}1981- \\
2008\end{array}$ & $\begin{array}{l}\text { Various regressions } \\
\text { methods }\end{array}$ & $\begin{array}{l}\text { Negative } \\
\text { relationship }\end{array}$ \\
\hline $\begin{array}{l}\text { Padhan et al., } \\
2019\end{array}$ & $\mathrm{~N}-11$ economies & $\begin{array}{l}1971- \\
2013\end{array}$ & $\begin{array}{l}\text { Panel techniques of co- } \\
\text { integration }\end{array}$ & Positive \\
\hline $\begin{array}{l}\text { Uzar and } \\
\text { Eyuboglu, } 2019\end{array}$ & Turkey & $\begin{array}{l}1984- \\
2014\end{array}$ & $\begin{array}{l}\text { ARDL and various other } \\
\text { regressions approaches }\end{array}$ & Positive \\
\hline $\begin{array}{l}\text { Baloch et al. } \\
(2020 \mathrm{~b})\end{array}$ & $\begin{array}{l}40 \text { sub-Saharan African } \\
\text { countries }\end{array}$ & $\begin{array}{l}2010- \\
2016\end{array}$ & D\&K regression & $\begin{array}{l}\text { positive } \\
\text { relationship }\end{array}$ \\
\hline $\begin{array}{l}\text { Rojas-Vallejos } \\
\text { and Lastuka } \\
(2020)\end{array}$ & $\begin{array}{l}68 \text { developed and } \\
\text { developing economies }\end{array}$ & $\begin{array}{l}1961- \\
2010\end{array}$ & $\begin{array}{l}\text { GMM-DIF, GMM-SYS, and } \\
\text { many other econometric } \\
\text { approaches }\end{array}$ & Trade-off \\
\hline $\begin{array}{l}\text { Khan and } \\
\text { Yahong, } 2021\end{array}$ & Pakistan & $\begin{array}{l}1971- \\
2017\end{array}$ & ARDL, Nonlinear ARDL & $\begin{array}{l}\text { Mixed } \\
\text { results }\end{array}$ \\
\hline
\end{tabular}

Note: OLS, FE, and GFE represents Ordinary Least Square, Fixed Effect, and Grouped Fixed Effect models respectively. Where, $P$-W is Prais-Winsten regression, ARDL is Auto-regressive Distributive Lag, D\&K is Driscoll and Kraay Regression model. Similarly, GMM-DIF and GMM-SYS represents Generalized Movement Model-Difference and Generalized Movement Model-System Models respectively. 


\section{Methodology \\ 3.1. Data}

For the analysis of current study we uses cross-country panel data of 18 Asian developing economies from 2006-2017 (for detail see Appendix-1, Table 4). The variables contains the model of this study are environmental degradation, income inequality, Inflation, foreign direct investment, population growth, percentage of forest area, access to electricity, and industrialization. In this study we used both $\mathrm{CO} 2 \mathrm{e}$ and EFP as proxies for environmental degradation, Gini coefficient as a proxy for income inequality, inflation calculated as the consumer price index (CPI), FDI measure the inflow of foreign direct investment, population growth calculated as annually population growth rate, forest area only calculated the percentage of forest area out of total land area, access to electricity (\% of total population, and manufacture, value added (\% of GDP) as the proxy for industrialization. The data of income inequality and environmental degradation are only available for limited years and countries. The data of $\mathrm{CO}_{2} \mathrm{e}$, income inequality, inflation, FDI, population growth, forest area, access to electricity, and industrialization are borrowed for World Development Indicator (WDI), while the data for EFP are gathered from Global Footprint Network (GFN). According to WDI, CO2e is calculated as the total emissions of carbon dioxide per capita in metric tons. While the EFP was introduced by (Rees, 1992) to measure environmental pollution because of human consumption with regenerative biological capacity. According to (Rees, 1992), EFP also measures the degradation of the natural resources as a result of economic activities. On the other hand, EFP is a measuring scale of human's demand on nature. The indicator of EFP is the summation of grazing land, forest area, crop-land, fishing ground, and infrastructure footprint (Charfeddine and Mrabet, 2017). The variables definition and descriptions are shown in Table 2.

\section{Table 2}

Variables' definition and data sources. 


\begin{tabular}{|c|c|c|c|}
\hline Symbols & Variables & Definition & Main/control \\
\hline EFP & $\begin{array}{l}\text { Ecological } \\
\text { footprint }\end{array}$ & Ecological Footprint consumption per capita & Main \\
\hline $\mathrm{CO} 2 \mathrm{e}$ & $\begin{array}{l}\text { Carbon } \\
\text { emissions }\end{array}$ & Carbon emission per capita metric tons & Main \\
\hline Gini & $\begin{array}{l}\text { Gini } \\
\text { index/coefficient }\end{array}$ & $\begin{array}{l}\text { Gini index/coefficient estimates the degree to which } \\
\text { the gap of income among households or individuals } \\
\text { deviates from a perfectly equal distribution. where: } \\
100 \text {, indicates perfect inequality, and } 0 \text { signifies } \\
\text { perfect equality }\end{array}$ & Main \\
\hline FDI & $\begin{array}{l}\text { Foreign direct } \\
\text { investment }\end{array}$ & The inflow of foreign direct investment per capita & Control \\
\hline Pop & $\begin{array}{l}\text { Population } \\
\text { growth }\end{array}$ & Population growth (annual \%) & Control \\
\hline $\mathrm{AE}$ & $\begin{array}{l}\text { Access to } \\
\text { electricity }\end{array}$ & Access to electricity (\% of total population) & Control \\
\hline FA & Forest area & Forest area (\% of total land area) & Control \\
\hline INF & Inflation & Inflation, consumer prices (annual \%) & Control \\
\hline IND & $\begin{array}{l}\text { Manufacture } \\
\text { value added }\end{array}$ & Manufacturing, value added (\% of GDP) & Control \\
\hline
\end{tabular}

\section{Note: mostly data were collected from World Development Indicators (WDI)}

The current study explores the nexus between income inequality and environmental degradation by incorporating inflation, FDI, population growth, forest area, access to electricity, and industrialization as control variables. The choice of variables selection and variables measurement are reliable and consistent with the past research studies (Koçak et al., 2019). The selection of variables used in the study's models is interested and motivated in the spirit of Sustainable Development Goals (SGDs). SDGs aiming to minimize all form of social and economic inequalities; managing inflation; facilitating sustainable economic growth with foreign direct investment; controlling population growth, reducing dependency on fossil fuel energy and maximize access to renewable and environmental friendly energy; controlling deforestation to control climate change and protect environment; support industrialization process by encouraging renewable energy.

\subsection{Econometric strategy}

In this study we uses Driscoll and Kraay (D\&K) standard error regression approach developed by (Driscoll and Kraay, 1998). The D\&K standard error regression approach have been utilized by many researchers in similar studies, such as (Knight, 2014; Majeed and Mazhar, 2019; Zhang et al., 2020). The panel data might have many problems including autocorrelation, heteroscedasticity, and cross-sectional 
dependency. Therefore, to handle these possible issues in panel data, we consider and prefers the D\&K standard error regression approach and re-analyze all the models (Jebli et al, 2016; Murshed et al., 2020). It creating a standard error through taking the mean of the product of explanatory variables along with residual which is robust against cross-sectional dependency. Additionally, this approach has the most effective tools and guaranteed if in case there is missing observations in the series of panel data. Besides, D\&K standard error approach is useful for balanced panel series as well as for unbalanced panel data series. Further, D\&K regression technique permits long time dimension and flexibility because it uses a non-parametric approach. Therefore, in current study we incorporated a D\&K standard error for Pooled Ordinary Least Square (POLS) approach through a multiple linear regression model which can be expressed as follows:

$y_{i, t}=\beta 0+X_{i, t} \beta_{1}+\varepsilon_{i}$

Where: $\mathrm{i}=1,2,3, \ldots \ldots, \mathrm{N}, \mathrm{t}=1,2,3, \ldots ., \mathrm{T}$ ( $\mathrm{N}$ represents panel of countries, while $\mathrm{T}$ represents of years). $y_{i, t}$ represents regressand variables and $X_{i, t}$ comprises all regressors (all dependent and independent variables mentioned in Table 1). The D\&K standard error regression technique is the most commonly and suitable econometric method in the recent work of (Azam and Khan 2016; Baloch et al., 2020a; Baloch et al., 2020b; Majeed and Mzhar, 2019; Zhang et al., 2019).

\section{Empirical Results And Discussion}

In our work, we applied D\&K standard error regression techniques to check the nexus between income inequality and environmental vulnerability in term of CO2e and EFP for the panel of 18 Asian developing economies. The empirical justification and estimation of this work have been analyzed in two steps. In the first step, the study have taken the environmental degradation (both $\mathrm{CO} 2 \mathrm{e}$ and EFP) as a response variable, while in the second step income inequality (Gini coefficient) considered as a dependent variable. Since for the ease of interpretation, the analysis of this study is based on $\log (I n)$ values of panel data series, the coefficient of long run elasticity of Ininf, Infa, Infdi, Inpopg, Inace, and Iaindu are statistically equal to EFP, CO2e and Gini coefficient with respect to inflation, forest area, FDI, population growth, access to electricity, and industrialization respectively.

The estimated results from D\&K standard error regression models are presented in Tables 3 and 4. In Model I of Table 3, we used Gini coefficient (Ingini) as a measure for income inequality which is positive and significant with EFP. This suggests that a 1 percent rise in the income inequality to increase EFP (proxy for environmental degradation) by $1.965 \%$. Similarly, in Model II of Table 3 , the coefficient of income inequality is also positive and significant with $\mathrm{CO} e$. This indicates that increase in income inequality leads to increase $\mathrm{CO}_{2} \mathrm{e}$ (proxy for environmental degradation) by $0.542 \%$. Whereas, in Model III of Table 4, the coefficient of EFP is positive and significant with income inequality. This infers that 1 percent growth in the amount of EFP leads to rise income inequality by $0.120 \%$. Likewise, the coefficient of income $\mathrm{CO} 2 \mathrm{e}$ is also positive and statistically significant even at $10 \%$ level. This suggests that $1 \%$ increase in the coefficient of CO2e leads to increase income inequality by $0.025 \%$. These estimated 
results support the evidence for the existence of trade-off relationship between income inequality and environmental protection. As for Model I and II of Table 3, a positive effect of income inequality on environmental degradation is justifiable for Asian developing economies. Because, low-income people living in these regions excessively misuse natural resources in form of water, food, and energy to fulfill their basic needs and sustain their livelihood. The excessive usage of natural resources leads to environmental degradation (Baloch et al., 2020a). Another possible explanation could be that income inequality in Asian developing economies may decrease the level of education and raise the affordability to consume high-emitting sources of energy among high-income people. Therefore, lack of awareness in low-income people and high affordability of energy consumption among high-income people increases environmental degradation in the form of EFP and CO2e. As mentioned by Demir et al. (2019), income inequality in least developed economies strengthens the industrialists and capital owners who is commonly investing in outdated and high-emitted technology to increase their income and thereby degrading environmental quality. This empirical findings also emphasize the theoretically ambiguous hypothesis of Boyce (1994) that rising income inequality generates class difference (power-gap) between poor and rich in a society that leads to worsen the environmental quality. Because the high-income people take advantage of the environment, while the low-income people cannot take the advantage because all costs are impose on them. Our empirical results urge that reducing inequality could help to control environmental degradation by reducing EFP and CO2e. Additionally, with the wide income gap, lowincome people tends to excessively exploit the environmental resources to sustain their livelihood, suggesting rising income inequality is not only social and economic issue but also an environmental problem. Our findings are in line with the empirical results of Bae (2018) for G-20 economies, Knight et al. (2017) for developed economies, Liu et al. (2019) for provincial economies of China, Masud et al. (2018) for ASEAN 5 economies, and Zhang and Zhao (2014) for regional economies of China; conversely, the our results are contradict to Demir et al. (2019) for Turkey and Grunewald et al. (2017) for Middle-income and Low-income economies. To the best of our knowledge, this empirically contradiction with our empirical work is because the dataset we used is not different i.e. Asian developing economies, and also we have applied an different and advance methodological approach to obtain our empirical results.

As for Models III and IV of Table 4, it infers that higher EFP and CO2e is likely to increase income inequality in Asian developing economies. Therefore, serious steps taken to reduce environmental degradation in order to control widening income gap. The findings of current study is justifiable for lowincome and developing economies like Asian developing countries because, to reduce extreme poverty, it is essential establish a new setup of industrial economy. In developing economies, in mostly cases, the industrialization process failed to reduce poverty, rather high-income people take the advantage of industrialization process and the cost of environmental degradation impose on low-income people, that further increases income gap between rich and poor. The adverse impact brought by industrialization process in terms of ecological vulnerability makes huge losses to the socioeconomic classes and eventually reduce the capacity of policy makers to reduce poverty and income inequality (Khan and Yahong, 2021). Furthermore, mostly developing economies initiate development projects to support lowincome people without considering environmental degradation, since capital owners and high-income 
people take advantages of these development projects. As a result, they investing in industries by providing high-emitting energy sources that contributes to rise in environmental vulnerability and thereby high income inequality (Grunewald et al., 2017). Additionally, Asian developing economies are often facing the high financial, technological, and low adoptive capacity during economic activities. In order to overwhelmed these constraints and maintain economic steady flow, developing economies may compromise on the quality of environment (Baloch et al., 2020b).

The above empirical results describes a clear image of the existing of complex trade-off situation between income inequality and environmental protection in the Asian developing economies. On the basis of above strong empirical evidence that is income inequality is harmful for environmental quality, although efforts toward reduction of poverty and income inequality leads to an increase in environmental degradation. It reveals that there is conflict and ambiguity between policies aiming to control all types of poverty (including income inequality) and environmental degradation. The present practices regarding economic and environmental policies to reduce poverty are increasing income inequality and not environmental-friendly. Therefore, it is necessary to devise both economic and environmental policies that particularly considering income inequality and environmental degradation. To this end, policymakers of selected region should educate poor as well as rich people to employ toward sustainable resource consumption, because mostly low-income people of selected region based on agriculture. Moreover, concern authorities of these developing economies should impose strict regulations regarding environment that could be helpful in reduce environmental degradation and also raising income inequality.

Regarding control variables used in the analysis of this study, as can be seen in Model I Table 3, inflation has a statistically significant and negative effect on environmental degradation. A I percent increase in the coefficient of inflation rate will degrading environmental quality in terms of EFP by 0.02 percent. Similarly, in Model II of Table 3, inflation has negative and statistically significant relationship with cO2e. It suggests that a 1 percent increase in the inflation rate will degrading environmental by 0.008 percent in Asian developing economies. Whereas, in Models III and IV of Table 4, inflation rate has positive and statistically significant association with income inequality. A 1 percent increase in the coefficient of inflation is contributing to increase income inequality by 0.06 and 0.05 percent respectively. The positive relationship between inflation and environmental degradation suggesting that increasing inflation reduces environmental degradation particularly in the short-run, as suggested by (Khan, 2019; Khan and Yahong 2021; Malik et al., 2020) for Pakistan. In term of FDI, it benefits economies in multiple ways as it not only allows technology spillover and knowledge sharing, but also improve the capacity of employment and production (Oxelheim and Ghauri, 2008). However, the findings of Models I and II of Table 3 suggests positive and statistically significant relationship between FDI and environmental degradation. While the coefficient of FDI is negative and statistically significant with income inequality as shown in Models III and IV of Table 4. The findings indicates that FDI can increases environmental degradation, while the greater ratio of FDI can help to reduce income inequality by increasing the equality of life. Our findings are in line with empirical work of (Malik et al., 2021) for Pakistan. 
Next, the coefficient of access to electricity (Inace) is statistically significant and positive with both EFP and $\mathrm{CO} 2 \mathrm{e}$ while, it has an insignificant impact on income inequality. it indicates that access to electricity can increase environmental degradation and can play an vital role in achieving Sustainable Development Goals (SDGs), which help to decrease inequality and poverty. However, the immense usage of cheap energy consumption and massive utilization of fossil fuels badly effect quality of environmental quality. Our empirical findings coincide with the work of (Danish, 2020) for sub-Saharan African countries) and (Malik et al., 2020) for Pakistan. The impact of the rest of the control variables on environmetal degradation and income inequality are as follow: (i) population growth rate (Inpopg) has significant positive effect on both EFP and CO2e while, it has negative and statistically significant relationship with income inequality. (ii) Forest area (Infa) is a significant and negative relationship with environmental degradation while, it has positive and statistically significant impact on income inequality. (iii) Industrialization and value added (Inind $u$ ) has negative relationship with environmental quality and positive with income inequality as shown in Tables 3 and 4.

Here, it is worth mentioning that this study have incorporated two proxies for environmental degradation (ecological footprints/EFP and carbon emissions CO2e) to check the robustness of our analysis. The findings of obtained from D\&K regression by using EFP and CO2e are consistent with each other which confirms the reliability and validity of our analysis.

\section{Table 3}

Relationship between ecological footprints, carbon emissions, and income inequality: D\&K standard error regression model. 


\begin{tabular}{|c|c|c|c|c|}
\hline \multicolumn{5}{|c|}{ Dependent variable = environmental degradation } \\
\hline \multirow{3}{*}{ Regressor } & \multicolumn{2}{|c|}{ D\&K regression with EFP $(I)$} & \multicolumn{2}{|c|}{ D\&K regression with $\mathrm{CO} 2 \mathrm{e}(\mathrm{II})$} \\
\hline & Coefficient & Drisc/Kraay & Coefficient & Drisc/Kraay \\
\hline & & Std. Err & & Std. Err \\
\hline Ingini & $1.965^{\star \star \star}$ & 0.179 & $0.542^{\star \star \star}$ & 0.158 \\
\hline Ininf & $-.021 * \star$ & 0.009 & -.008 & 0.007 \\
\hline Infa & 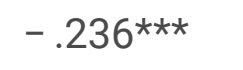 & 0.047 & $-.287 * \star \star$ & 0.043 \\
\hline Infdi & $0.324 * \star \star$ & 0.071 & $0.234 \star \star$ & 0.081 \\
\hline Inpopg & 0.072 & 0.090 & $0.262^{\star \star *}$ & 0.056 \\
\hline Inace & $0.021 * \star \star$ & 0.001 & $0.050 * \star *$ & 0.002 \\
\hline Inindu & $-.028 * \star$ & 0.011 & $-.120 * \star \star$ & 0.016 \\
\hline Constant & $-7.764^{\star \star \star}$ & 0.789 & $-5.01^{\star \star \star *}$ & 0.488 \\
\hline R-Squared & 0.622 & & 0.690 & \\
\hline F-statistic & 681.82 & & 1060.97 & \\
\hline Prob. & 0.000 & & 0.000 & \\
\hline Max: lag & Auto & & Auto & \\
\hline Root-MSE & 0.459 & & 0.594 & \\
\hline Observation & 216 & & 216 & \\
\hline Group & 18 & & 18 & \\
\hline Note: $* * *$ shc & significance & evel at $1 \%$, wh & ** show at 5 & \\
\hline
\end{tabular}

\section{Table 4}

Relationship between income inequality, ecological footprints and carbon emissions: D\&K standard error regression model. 


\begin{tabular}{|c|c|c|c|c|}
\hline \multicolumn{5}{|c|}{ Dependent variable = Income inequality } \\
\hline \multirow{3}{*}{ Regressor } & \multicolumn{2}{|c|}{ D\&K regression with Gini coeff (C) } & \multicolumn{2}{|c|}{ D\&K regression with Gini coeff (D) } \\
\hline & Coefficient & Drisc/Kraay & Coefficient & Drisc/Kraay \\
\hline & & Std. Err & & Std. Err \\
\hline Inefp & 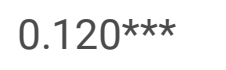 & 0.030 & & \\
\hline Inco2e & & & $0.025^{\star}$ & 0.011 \\
\hline Ininf & $0.006 * \star$ & .002 & 0.005 & 0.003 \\
\hline Infa & $0.062^{\star \star \star}$ & 0.006 & $0.051^{\star \star \star}$ & 0.008 \\
\hline Infdi & $-.045^{\star \star \star}$ & .009 & $-.014^{\star}$ & 0.006 \\
\hline Inpopg & $-.076 * \star \star$ & 0.021 & $-.094^{\star \star \star}$ & 0.056 \\
\hline Inace & -.003 & 0.001 & 0.001 & 0.001 \\
\hline Inindu & $0.043^{\star \star}$ & 0.002 & $0.054 * \star \star$ & 0.004 \\
\hline Constant & $3.451^{\star \star \star}$ & 0.093 & $3.378 * \star \star$ & 0.076 \\
\hline R-Squared & 0.469 & & 0.315 & \\
\hline F-statistic & 135.25 & & 174.97 & \\
\hline Prob. & 0.000 & & 0.000 & \\
\hline Max: lag & Auto & & Auto & \\
\hline Root-MSE & 0.113 & & 0.129 & \\
\hline Observation & 216 & & 216 & \\
\hline Group & 18 & & 18 & \\
\hline Note: $* * \star$ shc & significance & $t 1 \%, * *$ show at & hile * show & cance level at 10 \\
\hline
\end{tabular}

\section{Conclusion And Policy Implications}

Environmental quality and income inequality are linked with each other and should be taken into account to achieve Sustainable Development Goals (SDGs). The current research study analyzed the relationship between environmental degradation and income inequality by using the data of 18 Asian developing economies from 2006 to 2017. The study has also utilized as many as possible control group variables such as inflation, foreign direct investment (FDI), access to electricity, population growth, forest area, and industrialization. The empirically ambiguous findings reveal the existence of trade-off situation between environmental protection and income inequality. It infers that measures taken for environmental protection leads to increase income inequality and therefore addressing this concern at its top priority has 
become more challenging and complex. Moreover, population growth is helpful to control income inequality but it detrimental for the quality of environment. This contrast between environmental protection and income inequality creates a contradictory and alarming situation for the achievement of United Nations (UN) targeted development goals. When aiming to protect environment, the socioeconomic wellbeing of the poor people might be compromised thus, government officials of targeted economies should take serious steps by policy implementation that economic wellbeing along with ecological protections is the crucial goal of development. The most crucial and possible solution is to implement win to win policy that uphold environmental protection along with people's economic wellbeing and ensure other important development goals. For example, FDI plays a vital role in increasing economic growth and restoring economic wellbeing of the poor people along with controlling income inequality but at the high environmental costs. Therefore, introducing environmental-friendly energy sources to attract foreign investors can reduce environmental costs along with controlling income inequality and poverty. Additionally, estimated findings reveal that both EFP and CO2e measures of environmental degradation leads to increase income inequality. It infers that controlling environmental quality would be helpful to reduce income inequality. Therefore, government authorities and policymakers of investigated countries should invest more and apply mitigation policies and educate people to sustainably utilize natural resources. At the same time, concern authorities should implement strict regulation regarding environmental protection by considering the possible impact on people.

Furthermore, the empirical findings of current study has significant policies implications as some developing countries around the globe are presently make efforts to address issues surrounding both environmental degradation and economic inequalities. If controlling income inequality by boosting income level for poor population of the society increase environmental degradation in terms of EFP and CO2e, then this phenomena represents a big policy contest for government. In the past some researchers have suggested some policy important policy implications that targets either income inequality or environmental degradation. In this study we indicates that this two issues must be carefully considered together when implementing policy. First, the policy that could address this empirically ambiguous situation effectively is a revenue neutral redistributive toxic emissions tax that would incentivize emissions reduction in the most cost effective conceivable way. While the allocation of these tax-revenue could be utilize to improve public services used by low income people. For example, Boyce (2018) suggests some empirical evidence to support this type of policy implications. According to him, revenue neutral emission-tax with equal per-head dividends would be a progressive policy with the top quintile paying more for the emissions tax than they get from the repayment. Second, the promotion and up gradation of electrification with environmental-friendly and renewable energy (wind or solar energy) in rural areas. These up gradation in terms of renewable energy could rises employment opportunities thus controls income inequality (Dinkelman, 2011).

Although, the empirical results have vast importance towards policy implications, but, not without some limitations, that need to highlight and extends for the future studies. The current research incorporated Gini coefficient as measure of income inequality while EFP and CO2e utilized for environmental degradation respectively. In a productive way, this study can be extended to utilize other measures for 
environmental degradation and income inequality, and can be verify whether the empirical results obtained from this study are consistent and robust to other indicators of environmental degradation and income inequality.

Table 5

List of investigated countries

\begin{tabular}{|lll|}
\hline Bangladesh & Indonesia & Myanmar \\
\hline Bhutan & Lao PDR & Pakistan \\
\hline China & Malaysia & Philippines \\
\hline Fiji & Maldives & Samoa \\
\hline India & Magnolia & Sri Lanka \\
Thailand & Timor-Leste & Vietnam \\
\hline
\end{tabular}

\section{Declarations}

\section{Availability of data}

The data that support the findings of this study are openly available at the following URL https://datacatalog.worldbank.org/dataset/world-development-indicators

\section{Authors' contribution:}

Mr. Salim Khan: Performed Conceptualization, Methodology, Formal analysis, Investigation, Writing (original draft), and Software coding. Dr. Wang Yahong: performed Validation, Software coding, Resource Review \& editing, discussed the results and supervised manuscript status.

\section{Funding}

The research was funded by the National Social Science Foundation of China (Grant No. 18BJY164), Education Department of Henan Province (Grant No. 19A790025), National natural Science Foundation of China (Grant No. 41601566), and Humanities and Social Science Project of Education Ministry (14YJCZH128).

Ethical approval: Not applicable

Consent to practice: Not applicable

Consent to publish: Not applicable

\section{Competing interests}


The authors declare that they have no competing interests

\section{References}

1. Abbas S, Kousar S, Pervaiz A (2021) Effects of energy consumption and ecological footprint on CO 2 emissions: an empirical evidence from Pakistan. Environment, Development and Sustainability, pp.1-18

2. Aslanidis N, Iranzo S (2009) Environment and development: is there a Kuznets curve for $\mathrm{CO} 2$ emissions? Appl Econ 41(6):803-810

3. Aydin M (2019) Renewable and non-renewable electricity consumption-economic growth nexus: evidence from OECD countries. Renewable energy 136:599-606

4. Azam M, Khan AQ (2016) Urbanization and environmental degradation: Evidence from four SAARC countries-Bangladesh, India, Pakistan, and Sri Lanka. Environ Prog Sustain Energy 35(3):823-832

5. Bae JH (2018) Impacts of income inequality on $\mathrm{CO} 2$ emission under different climate change mitigation policies. Korean Economic Review 34:187-211

6. Baloch A, Shah SZ, Noor ZM, Magsi HB (2018) The nexus between income inequality, economic growth and environmental degradation in Pakistan. GeoJournal 83(2):207-222

7. Baloch MA, Zhang J, Iqbal K, lqbal Z (2019b) The effect of financial development on ecological footprint in BRI countries: evidence from panel data estimation. Environ Sci Pollut Res 26(6):61996208

8. Baloch MA, Khan SUD, Ulucak Z (2020a) Poverty and vulnerability of environmental degradation in Sub-Saharan African countries: what causes what? Struct Change Econ Dyn 54:143-149

9. Baloch MA, Khan SUD, Ulucak Z, Ahmad A (2020b) Analyzing the relationship between poverty, income inequality, and $\mathrm{CO} 2$ emission in Sub-Saharan African countries. Science of The Total Environment, 740, p.139867

10. Berthe A, Elie L (2015) Mechanisms explaining the impact of economic inequality on environmental deterioration. Ecological economics 116:191-200

11. Bhattacharya $\mathrm{H}$ (2020) Environmental and socio-economic sustainability in India: evidence from $\mathrm{CO} 2$ emission and economic inequality relationship. Journal of Environmental Economics Policy 9(1):5776

12. Boyce JK (1994) Inequality as a cause of environmental degradation. Ecological economics 11(3):169-178

13. Boyce JK (2018) Carbon pricing: Effectiveness and equity. Ecol Econ 150:52-61

14. Charfeddine L, Mrabet Z (2017) The impact of economic development and social-political factors on ecological footprint: A panel data analysis for 15 MENA countries. Renew Sustain Energy Rev 76:138-154

15. Cropper M, Griffiths C (1994) The interaction of population growth and environmental quality. Am Econ Rev 84(2):250-254 
16. Danish (2020) Moving toward sustainable development: The relationship between water productivity, natural resource rent, international trade, and carbon dioxide emissions. Sustain Dev 28(4):540-549

17. Demir C, Cergibozan R, Gök A (2019) Income inequality and CO2 emissions: Empirical evidence from Turkey. Energy Environ 30(3):444-461

18. Dinkelman T (2011) The effects of rural electrification on employment: New evidence from South Africa. Am Econ Rev 101(7):3078-3108

19. Dorn F, Maxand S, Kneib T (2021) The dependence between income inequality and carbon emissions: A distributional copula analysis. Available at SSRN 3800302

20. Driscoll JC, Kraay AC (1998) Consistent covariance matrix estimation with spatially dependent panel data. Review of economics statistics 80(4):549-560

21. Duro JA, Teixidó-Figueras J (2013) Ecological footprint inequality across countries: The role of environment intensity, income and interaction effects. Ecol Econ 93:34-41

22. Edenhofer O, Pichs-Madruga R, Sokona Y, Farahani E, Kadner S, Seyboth K, Adler A, Baum I, Brunner, S., Eickemeier, P. and Kriemann B (2014) IPCC, 2014: Summary for policymakers, in climate change 2014: Mitigation of Climate Change. Contribution of Working Group III to the Fifth Assessment Report of the Intergovernmental Panel on Climate Change

23. Ekeocha DO (2021) Urbanization, inequality, economic development and ecological footprint: Searching for turning points and regional homogeneity in Africa. Journal of Cleaner Production, 291, p.125244

24. Finco MVA (2009) Poverty-environment trap: a non linear probit model applied to rural areas in the North of Brazil. American-Eurasian Journal of Agricultural Environmental Science 5(4):533-539

25. Forabosco F, Chitchyan Z, Mantovani R (2017) Methane, nitrous oxide emissions and mitigation strategies for livestock in developing countries: A review. South African Journal of Animal Science 47(3):268-280

26. Grossman GM, Krueger AB (1995) Economic growth and the environment. The quarterly journal of economics 110(2):353-377

27. Grunewald N, Klasen S, Martínez-Zarzoso I, Muris C (2017) The trade-off between income inequality and carbon dioxide emissions. Ecol Econ 142:249-256

28. Hailemariam A, Dzhumashev R, Shahbaz M (2020) Carbon emissions, income inequality and economic development. Empirical Economics 59(3):1139-1159

29. Hanewinkel M, Cullmann DA, Schelhaas MJ, Nabuurs GJ, Zimmermann NE (2013) Climate change may cause severe loss in the economic value of European forest land. Nature climate change 3(3):203-207

30. Heerink N, Mulatu A, Bulte E (2001) Income inequality and the environment: aggregation bias in environmental Kuznets curves. Ecol Econ 38(3):359-367

31. Holtz-Eakin D, Selden TM (1995) Stoking the fires? CO2 emissions and economic growth. Journal of public economics 57(1):85-101 
32. Jebli MB, Youssef SB, Ozturk I (2016) Testing environmental Kuznets curve hypothesis: The role of renewable and non-renewable energy consumption and trade in OECD countries. Ecol Ind 60:824831

33. Jorgenson A, Schor J, Huang X (2017) Income inequality and carbon emissions in the United States: a state-level analysis, 1997-2012. Ecol Econ 134:40-48

34. Kaika D, Zervas E (2013) The Environmental Kuznets Curve (EKC) theory-Part A: Concept, causes and the $\mathrm{CO} 2$ emissions case. Energy Policy 62:1392-1402

35. Kaika D, Zervas E (2013) The environmental Kuznets curve (EKC) theory. Part B: Critical issues. Energy Policy 62:1403-1411

36. Kazemzadeh E, Fuinhas JA, Koengkan M (2021) The impact of income inequality and economic complexity on ecological footprint: an analysis covering a long-time span. Journal of Environmental Economics and Policy, pp.1-21

37. Khan SAR (2019) The nexus between carbon emissions, poverty, economic growth, and logistics operations-empirical evidence from southeast Asian countries. Environ Sci Pollut Res 26(13):1321013220

38. Khan S, Yahong W (2021) Symmetric and Asymmetric Impact of Poverty, Income Inequality, and Population on Carbon Emission in Pakistan: New Evidence from ARDL and NARDL Co-Integration. Frontiers in Environmental Science, 9

39. Knight KW, Schor JB, Jorgenson AK (2017) Wealth inequality and carbon emissions in high-income countries. Social Currents 4(5):403-412

40. Koçak E, Ulucak R, Dedeoğlu M, Ulucak Z (2019) Is there a trade-off between sustainable society targets in Sub-Saharan Africa?. Sustainable Cities and Society, 51, p.101705

41. Kuznets S (1955) Economic Growth and Inequality Income. Am Econ Rev 45(1):1-28

42. Lawson ET, Gordon C, Schluchter W (2012) The dynamics of poverty-environment linkages in the coastal zone of Ghana. Ocean Coastal Management 67:30-38

43. Luqman M, Ahmad N, Bakhsh K (2019) Nuclear energy, renewable energy and economic growth in Pakistan: Evidence from non-linear autoregressive distributed lag model. Renewable Energy 139:1299-1309

44. Liu Q, Wang S, Zhang W, Li J, Kong Y (2019) Examining the effects of income inequality on CO2 emissions: Evidence from non-spatial and spatial perspectives. Appl Energy 236:163-171

45. Liu Y, Zhang M, Liu R (2020) The Impact of Income Inequality on Carbon Emissions in China: A Household-Level Analysis. Sustainability, 12(7), p.2715

46. Magnani E (2000) The Environmental Kuznets Curve, environmental protection policy and income distribution. Ecological economics 32(3):431-443

47. Majeed MT, Mazhar M (2019) Financial development and ecological footprint: A global panel data analysis. Pakistan Journal of Commerce Social Sciences (PJCSS) 13(2):487-514 
48. Malik MY, Latif K, Khan Z, Butt HD, Hussain M, Nadeem MA (2020) Symmetric and asymmetric impact of oil price, FDI and economic growth on carbon emission in Pakistan: Evidence from ARDL and non-linear ARDL approach. Science of the Total Environment, 726, p.138421

49. Masud MM, Kari FB, Banna H, Saifullah MK (2018) Does income inequality affect environmental sustainability? Evidence from the ASEAN-5. J Asia Pac Econ 23(2):213-228

50. Meinard $Y$ (2021) Rationalizing environmental decision-making through economic valuation?. Humanistyka I Przyrodoznawstwo, 25

51. Mikkelson GM (2019) Invisible hand or ecological footprint? Comparing social versus environmental impacts of recent economic growth. Organization \& Environment, p 1086026619885111

52. Mostafa MM (2010) A Bayesian approach to analyzing the ecological footprint of 140 nations. Ecol Ind 10(4):808-817

53. Murshed M, Nurmakhanova M, Elheddad M, Ahmed R (2020) Value addition in the services sector and its heterogeneous impacts on $\mathrm{CO} 2$ emissions: revisiting the EKC hypothesis for the OPEC using panel spatial estimation techniques. Environ Sci Pollut Res 27(31):38951-38973

54. Narayan PK, Narayan S (2010) Carbon dioxide emissions and economic growth: Panel data evidence from developing countries. Energy policy 38(1):661-666

55. Ota T (2017) Economic growth, income inequality and environment: assessing the applicability of the Kuznets hypotheses to Asia. Palgrave Communications 3(1):1-23

56. Oxelheim L, Ghauri P (2008) EU-China and the non-transparent race for inward FDI. J Asian Econ 19(4):358-370

57. Padhan H, Haouas I, Sahoo B, Heshmati A (2019) What matters for environmental quality in the Next Eleven Countries: economic growth or income inequality? Environ Sci Pollut Res 26(22):2312923148

58. Rai J, Soni S (2019) Approaches to environmental decision making through human-environment relationship perspectives. Journal of Geography Environment Earth Science International 18(4):1-13

59. Rees WE (1992) Ecological footprints and appropriated carrying capacity: What urban economics leaves out? Environ Urban 4:121-130. doi:10.1177/ 095624789200400212

60. Rojas-Vallejos J, Lastuka A (2020) The income inequality and carbon emissions trade-off revisited. Energy Policy, 139, p.111302

61. Ravallion M, Heil M, Jalan J (2000) Carbon emissions and income inequality. Oxf Econ Pap 52(4):651-669

62. Khan S, Yahong W (2021) Symmetric and Asymmetric Impact of Poverty, Income Inequality, and Population on Carbon Emission in Pakistan: New Evidence from ARDL and NARDL Co-Integration. Frontiers in Environmental Science, 9

63. Scolobig A, Lilliestam J (2016) Comparing approaches for the integration of stakeholder perspectives in environmental decision making. Resources, 5(4), p.37 
64. Solarin SA, Bello MO (2020) Energy innovations and environmental sustainability in the US: the roles of immigration and economic expansion using a maximum likelihood method. Science of The Total Environment, 712, p.135594

65. Steffen W, Richardson K, Rockström J, Cornell SE, Fetzer I, Bennett EM, Biggs R, Carpenter SR, De Vries W, De Wit CA, Folke C (2015) Planetary boundaries: Guiding human development on a changing planet. Science, 347(6223)

66. Tol RS (2002) Estimates of the damage costs of climate change. Part 1: Benchmark estimates. Environmental resource Economics 21(1):47-73

67. Torras M, Boyce JK (1998) Income, inequality, and pollution: a reassessment of the environmental Kuznets curve. Ecological economics 25(2):147-160

68. Tyler E, Boyd AS, Coetzee K, Winkler H (2017) A case study of South African mitigation actions (For the special issue on mitigation actions in five developing countries). In: Climate Change Mitigation Actions in Five Developing Countries. Routledge, pp 57-66

69. Ullah S, Awan MS (2019) Environmental Kuznets Curve and Income Inequality: Pooled Mean Group Estimation for Asian Developing Countries. Forman Journal of Economic Studies, 15

70. Uzar U, Eyuboglu K (2019) The nexus between income inequality and CO2 emissions in Turkey. J Clean Prod 227:149-157

71. Wang X (2014) Addressing failures of environmental information disclosure through administrative lawsuits in China: the paradox of legal mobilization. China-EU Law Journal 3(3-4):165-190

72. Wang M, Feng C (2017) Decomposition of energy-related CO2 emissions in China: an empirical analysis based on provincial panel data of three sectors. Applied energy 190:772-787

73. Wang Z, Zhang B, Wang B (2018) Renewable energy consumption, economic growth and human development index in Pakistan: evidence form simultaneous equation model. Journal of cleaner production, 184, pp.1081-1090

74. Xi X (2020) The cross-sectional impact of income inequality on life quality indicators. JABS 6(4):153-163

75. Zaidi S, Saidi K (2018) Environmental pollution, health expenditure and economic growth in the SubSaharan Africa countries: Panel ARDL approach. Sustainable cities society 41:833-840

76. Zhang J, Hassan ST, Iqbal K (2020) Toward achieving environmental sustainability target in Organization for Economic Cooperation and Development countries: The role of real income, research and development, and transport infrastructure. Sustain Dev 28(1):83-90

77. Zhang C, Zhao W (2014) Panel estimation for income inequality and CO2 emissions: A regional analysis in China. Appl Energy 136:382-392

78. Zhao J, Jiang Q, Dong X, Dong K (2021) Assessing energy poverty and its effect on CO2 emissions: The case of China. Energy Economics, 97, p.105191 